Article

\title{
Two New Flavonoids from the Nuts of Areca catechu
}

\author{
Mengfei Yuan ${ }^{\dagger}$, Yunlin Ao ${ }^{\dagger}$, Nan Yao, Jing Xie, Dongmei Zhang, Jian Zhang *, Xiaoqi Zhang * \\ and Wencai Ye
}

Institute of Traditional Chinese Medicine \& Natural Products, Guangdong Provincial Engineering Research Center for Modernazation of TCM, College of Pharmacy, Jinan University, Guangzhou 510632, China

* Correspondence: zzjj1205@126.com (J.Z.); xqzhang74@hotmail.com (X.Z.); Tel.: +86-133-1617-7202 (J.Z.); +86-020-8522-3994 (X.Z.)

+ These authors contributed equally to this work.

Received: 22 July 2019; Accepted: 6 August 2019; Published: 7 August 2019

check for updates

\begin{abstract}
Two new flavonoids, calquiquelignan M (1), calquiquelignan N (2), along with nine known compounds (3-11), were isolated from the nuts of Areca catechu (Palmae). The new structures, including absolute configurations, were established by a combination of spectroscopic data and electronic circular dichroism (ECD) calculation. The known compounds were identified by comparing their spectroscopic data with reported in the literature. The flavonoids compounds (1-8) were evaluated for their cytotoxicity activities against three human cancer cell lines. Compounds $\mathbf{1}$ and 2 exhibited a moderate cytotoxic activity against HepG2 cell lines with IC $_{50}$ values of 49.8 and $53.6 \mu \mathrm{M}$, respectively.
\end{abstract}

Keywords: Areca catechu; flavonoids; absolute configuration; cytotoxicity

\section{Introduction}

Areca nut is obtained from the fruit of the Areca catechu (Palmae), which is widely distributed in southeast Asia and southern China [1]. Areca nuts are regarded as a traditional Chinese medicine usually used for the treatment of indigestion, liver disorders, and also used as a vermifuge [2,3]. Previous pharmacological studies of areca nuts have demonstrated antibacterial, antioxidant, anti-inflammatory, antifungal, and anthelmintic activities [4,5]. In a search for novel and bioactive constituents from Chinese herbal medicines [6-10], our group had reported three new areca alkaloids from the nuts of $A$. catechu [11]. In our continuing investigation, two new flavonoids calquiquelignan $M$ (1), calquiquelignan $\mathrm{N}$ (2), and nine known compounds naringenin (3) [12], dihydrotricin (4) [13], sinesetin (5) [14], nobiletin (6) [15], 8-demethyleucalyptin (7) [16], eucalyptin (8) [16], (+)-isolariciresinol (9) [17], rhapontigenin (10) [18], glyceryl-2-vanillic acid methyl ester (11) [19], were isolated from the same plant parts as shown in Figure 1. The new structures, including absolute configurations, were elucidated by spectroscopic data and electronic circular dichroism (ECD) calculation, and the known ones were identified by comparison with data in the literature. Herein, we report the isolation, structure elucidation, and cytotoxic activities of these compounds. 


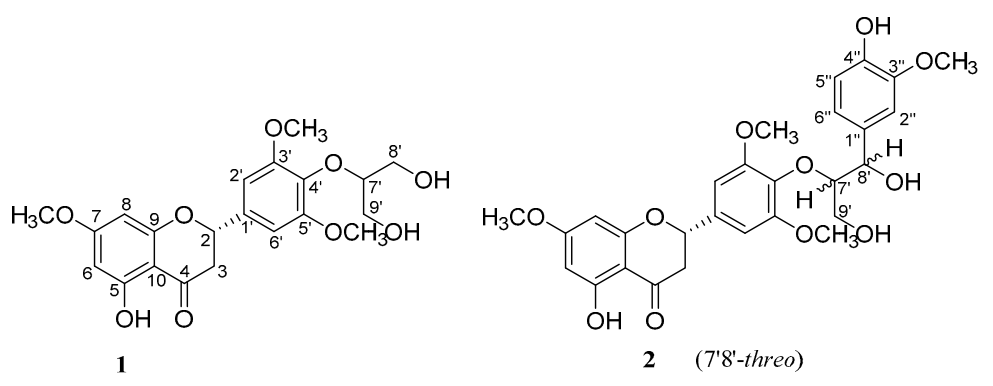<smiles>[R]c1cc([C@H]2CC(=O)c3c(O)cc(O)cc3O2)cc([R2])c1O</smiles><smiles>[R]c1cc(-c2cc(=O)c3c([R3])c([R])c(OC)c([R])c3o2)ccc1OC</smiles>
\begin{tabular}{lll}
\multicolumn{2}{r}{$\mathrm{R}_{1}$} & $\mathrm{R}_{2}$ \\
$\mathbf{3} \mathrm{OCH}_{3}$ & $\mathrm{OCH}_{3}$ \\
$\mathbf{4} \mathrm{H}$ & $\mathrm{H}$
\end{tabular} $\begin{array}{llll}\mathrm{R}_{1} & \mathrm{R}_{2} & \mathrm{R}_{3} & \mathrm{R}_{4}\end{array}$

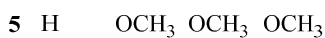
$6 \mathrm{OCH}_{3} \mathrm{OCH}_{3} \mathrm{OCH}_{3} \mathrm{OCH}_{3}$ $\begin{array}{llllll}7 & \mathrm{H} & \mathrm{CH}_{3} & \mathrm{OH} & \mathrm{H}\end{array}$<smiles>COc1cc([C@H]2c3cc(O)c(OC)cc3C[C@@H](CO)[C@H]2CO)ccc1O</smiles><smiles>COc1ccc(/C=C/c2cc(O)cc(O)c2)cc1O</smiles><smiles>COc1cc(C(C)=O)ccc1OC(CO)CO</smiles>

Figure 1. Chemical structures of $\mathbf{1}$ to $\mathbf{1 1}$.

\section{Results and Discussion}

\section{Structural Elucidation}

Calquiquelignan M (1) was isolated as a yellow powder. The molecular formula of $\mathbf{1}$ was assigned as $\mathrm{C}_{21} \mathrm{H}_{24} \mathrm{O}_{9}$ based on its HRESIMS at $m / z 443.1310[\mathrm{M}+\mathrm{Na}]^{+}$(calcd for $\mathrm{C}_{21} \mathrm{H}_{24} \mathrm{O}_{9} \mathrm{Na}$, 443.1313), indicating 10 degrees of unsaturation. The IR absorption showed the characteristic absorptions for hydroxyl $\left(3477 \mathrm{~cm}^{-1}\right)$, carbonyl $\left(1660 \mathrm{~cm}^{-1}\right)$ groups, and aromatic ring (1535 and $\left.1450 \mathrm{~cm}^{-1}\right)$. The UV spectrum exhibited absorption maxima at 287 and $208 \mathrm{~nm}$. The ${ }^{1} \mathrm{H}-\mathrm{NMR}$ spectrum indicated the presence of four aromatic protons $\left[\delta_{\mathrm{H}} 6.71\left(2 \mathrm{H}, \mathrm{s}, \mathrm{H}-2^{\prime} / 6^{\prime}\right), 6.09(1 \mathrm{H}, \mathrm{s}, \mathrm{H}-8), 6.08(1 \mathrm{H}, \mathrm{s}, \mathrm{H}-6)\right]$; two methines $\left[\delta_{\mathrm{H}} 5.36(1 \mathrm{H}, \mathrm{dd}, J=13.0,3.0 \mathrm{~Hz}, \mathrm{H}-2), 4.08\left(1 \mathrm{H}, \mathrm{m}, \mathrm{H}-7^{\prime}\right)\right]$; three methylenes $\left[\delta_{\mathrm{H}} 3.05\right.$ $(1 \mathrm{H}, \mathrm{dd}, J=17.0,13.0, \mathrm{H}-3 \alpha), 2.82(1 \mathrm{H}, \mathrm{dd}, J=17.0,3.0, \mathrm{H}-3 \beta), 3.77\left(2 \mathrm{H}, \mathrm{d}, J=3.4 \mathrm{~Hz}, \mathrm{H}-8^{\prime}\right), 3.85$ $\left.\left(2 \mathrm{H}, \mathrm{d}, J=3.4 \mathrm{~Hz}, \mathrm{H}-9^{\prime}\right)\right]$, and three methoxyls $\left[\delta_{\mathrm{H}} 3.91(6 \mathrm{H}, \mathrm{s}), 3.82(3 \mathrm{H}, \mathrm{s})\right]$. The ${ }^{13} \mathrm{C}-\mathrm{NMR}$ spectrum displayed twenty-one carbon signals, including a carbonyl, eight quaternary carbons, six methines, three methylenes, and three methoxyls. With the aid of ${ }^{1} \mathrm{H}-{ }^{1} \mathrm{H}$ COSY, HSQC, and HMBC experiments, all of the ${ }^{1} \mathrm{H}$ - and ${ }^{13} \mathrm{C}-\mathrm{NMR}$ signals of $\mathbf{1}$ were assigned as shown in Table 1.

The above data of 1 resembled those of dihydrotricin (3) [12], except for the presence of one methoxy and one glycerin unit carbon signals. The ${ }^{1} \mathrm{H}-{ }^{1} \mathrm{H}$ COSY correlations between $\delta_{\mathrm{H}} 3.85\left(\mathrm{H}_{2}-8^{\prime}\right)$ $-4.08\left(\mathrm{H}-7^{\prime}\right)-3.77\left(\mathrm{H}_{2}-9^{\prime}\right)$ confirmed the glycerin unit existence, and the HMBC correlations between $\mathrm{H}-7^{\prime}$ and $\mathrm{C}-4^{\prime}$ allowed the linkage between dihydroflavone fragment and glycerin fragment through the $\mathrm{C}-4^{\prime}-\mathrm{O}-\mathrm{C}-7^{\prime}$ bond. The HMBC correlations between $\delta_{\mathrm{H}} 3.82$ (methoxy) and C-7 led to the increased methoxy substitution position at C-7 (Figure 2). Finally, the absolute configuration of $\mathbf{1}$ was deduced using the computational calculation method. The experimental ECD spectrum of 1 showed positive Cotton effects at $342(\Delta \varepsilon+6.6), 260(\Delta \varepsilon+29.3) \mathrm{nm}$ and negative Cotton effects at $299(\Delta \varepsilon-7.0), 216$ $(\Delta \varepsilon-18.2) \mathrm{nm}$, which were similar to those in the quantum chemical ECD calculation in Gaussian 09 software (Figure 3) [20]. Accordingly, the absolute configuration of $\mathbf{1}$ was determined as $2 S$. 
Table 1. ${ }^{1} \mathrm{H}$ - and ${ }^{13} \mathrm{C}-\mathrm{NMR}$ data of $\mathbf{1}$ and $\mathbf{2}(\delta$ in ppm, $J$ in $\mathrm{Hz}$ ).

\begin{tabular}{|c|c|c|c|c|c|}
\hline \multirow{2}{*}{ Position } & \multicolumn{3}{|c|}{$1^{a}$} & \multicolumn{2}{|l|}{$2^{b}$} \\
\hline & & $\delta_{H}$ & $\delta_{\mathrm{C}}$ & $\delta_{H}$ & $\delta_{C}$ \\
\hline 2 & & $5.36 \mathrm{dd}(13.0,3.0)$ & 79.4 & $5.45 \mathrm{dd}(11.0,6.0)$ & 80.7 \\
\hline 3 & $\alpha$ & $3.05 \mathrm{dd}(17.0,13.0)$ & 43.8 & $3.18 \mathrm{dd}(16.5,11.0)$ & 44.4 \\
\hline 4 & & - & 195.5 & - & 197.8 \\
\hline 5 & & - & 164.4 & - & 165.3 \\
\hline 6 & & $6.08 \mathrm{~s}$ & 95.4 & $6.08 \mathrm{~s}$ & 95.9 \\
\hline 7 & & - & 168.2 & - & 169.6 \\
\hline 8 & & $6.09 \mathrm{~s}$ & 94.6 & $6.12 \mathrm{~s}$ & 95.1 \\
\hline 9 & & - & 162.6 & - & 164.4 \\
\hline 10 & & - & 103.2 & - & 104.1 \\
\hline $1^{\prime}$ & & - & 135.0 & - & 136.5 \\
\hline $2^{\prime} / 6^{\prime}$ & & $6.71 \mathrm{~s}$ & 103.4 & $6.87 \mathrm{~s}$ & 104.9 \\
\hline $3^{\prime} / 5^{\prime}$ & & - & 153.6 & - & 154.4 \\
\hline $4^{\prime}$ & & - & 135.7 & - & 137.4 \\
\hline $7^{\prime}$ & & $4.08 \mathrm{~m}$ & 85.0 & $4.14 \mathrm{~m}$ & 88.9 \\
\hline $8^{\prime}$ & & $3.85 \mathrm{~d}(3.4)$ & 62.7 & $5.02 \mathrm{~d}(6.7)$ & 74.5 \\
\hline $9^{\prime}$ & $\begin{array}{l}\alpha \\
b\end{array}$ & $3.77 \mathrm{~d}(3.4)$ & 62.7 & $\begin{array}{l}3.79 \mathrm{~m} \\
3.37 \mathrm{~m}\end{array}$ & 61.8 \\
\hline $1^{\prime \prime}$ & & - & - & - & 133.5 \\
\hline $2^{\prime \prime}$ & & - & - & $7.03 \mathrm{~s}$ & 111.7 \\
\hline $3^{\prime \prime}$ & & - & - & - & 148.7 \\
\hline $4^{\prime \prime}$ & & - & - & - & 147.2 \\
\hline $5^{\prime \prime}$ & & - & - & $6.77 \mathrm{~d}(8.0)$ & 115.8 \\
\hline $6^{\prime \prime}$ & & & - & $6.89 \mathrm{~d}(8.0)$ & 120.8 \\
\hline $7-\mathrm{OCH}_{3}$ & & $3.82 \mathrm{~s}$ & 55.9 & $3.85 \mathrm{~s}$ & 56.4 \\
\hline $3^{\prime}-\mathrm{OCH}_{3}$ & & $3.91 \mathrm{~s}$ & 56.5 & $3.89 \mathrm{~s}$ & 56.8 \\
\hline $5^{\prime}-\mathrm{OCH}_{3}$ & & $3.91 \mathrm{~s}$ & 56.5 & $3.89 \mathrm{~s}$ & 56.8 \\
\hline $3^{\prime \prime}-\mathrm{OCH}_{3}$ & & - & - & $3.84 \mathrm{~s}$ & 56.3 \\
\hline
\end{tabular}

${ }^{a}$ Measured in $\mathrm{CDCl}_{3} \cdot{ }^{\mathrm{b}}$ Measured in $\mathrm{CD}_{3} \mathrm{OD}$.

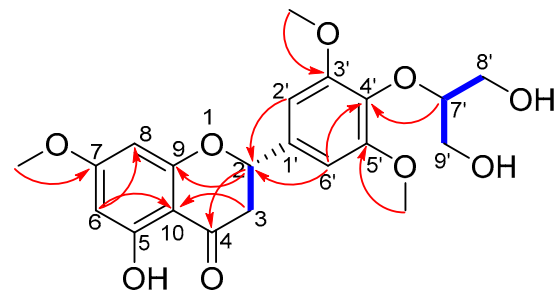

$-{ }^{1} \mathrm{H}-{ }^{1} \mathrm{H}$ COSY $\mathrm{HMBC}$

Figure 2. ${ }^{1} \mathrm{H}-{ }^{1} \mathrm{H}$ COSY and key HMBC correlations of $\mathbf{1}$.

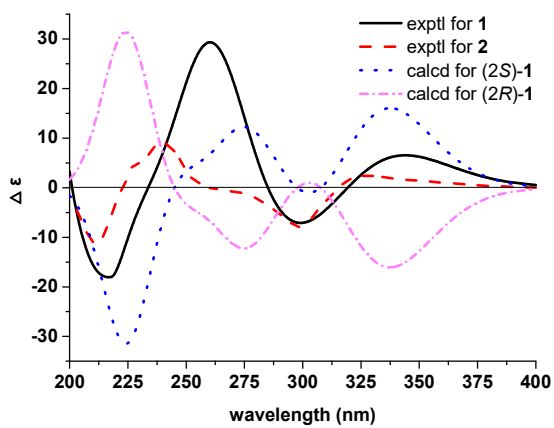

Figure 3. Experimental electronic circular dichroism (ECD) spectra for $\mathbf{1}$ and 2; and calculated for $\mathbf{1}$. 
Calquiquelignan $\mathrm{N}$ (2) was obtained as a yellow powder, possessed a molecular formula $\mathrm{C}_{28} \mathrm{H}_{30} \mathrm{O}_{11}$ as established by its HR-ESI-MS at $m / z 565.1685[\mathrm{M}+\mathrm{Na}]^{+}$(calcd for $\mathrm{C}_{28} \mathrm{H}_{30} \mathrm{O}_{11} \mathrm{Na}, 565.1680$ ). The IR absorption revealed the presence of hydroxyl $\left(3443 \mathrm{~cm}^{-1}\right)$, carbonyl $\left(1651 \mathrm{~cm}^{-1}\right)$ groups, as well as an aromatic ring (1511 and $1429 \mathrm{~cm}^{-1}$ ). The UV spectrum showed the characteristic absorption maxima at 287,230 , and $208 \mathrm{~nm}$. The ${ }^{1} \mathrm{H}-\mathrm{NMR}$ spectrum indicated the presence of seven aromatic protons $\left[\delta_{\mathrm{H}} 7.03\right.$ $\left(1 \mathrm{H}, \mathrm{s}, \mathrm{H}-2^{\prime \prime}\right), 6.89\left(1 \mathrm{H}, \mathrm{d}, J=8.0 \mathrm{~Hz}, \mathrm{H}-6^{\prime \prime}\right), 6.87\left(2 \mathrm{H}, \mathrm{s}, \mathrm{H}-2^{\prime} / 6^{\prime}\right), 6.77\left(1 \mathrm{H}, \mathrm{d}, J=8.0 \mathrm{~Hz}, \mathrm{H}-5^{\prime \prime}\right), 6.12(1 \mathrm{H}$, s, H-8), $6.08(1 \mathrm{H}, \mathrm{s}, \mathrm{H}-6)]$; three methines [ $\delta_{\mathrm{H}} 5.45(1 \mathrm{H}, \mathrm{dd}, J=11.0,6.0 \mathrm{~Hz}, \mathrm{H}-2), 5.02(1 \mathrm{H}, \mathrm{d}, J=6.7, \mathrm{~Hz}$, $\left.\left.\mathrm{H}-8^{\prime}\right), 4.14\left(1 \mathrm{H}, \mathrm{m}, \mathrm{H}-7^{\prime}\right)\right]$; two methylenes [ $\delta_{\mathrm{H}} 3.18(1 \mathrm{H}, \mathrm{dd}, J=16.5,11.0, \mathrm{H}-3 \alpha), 2.81(1 \mathrm{H}, \mathrm{dd}, J=16.5$, 6.0, H-3ß), $\left.3.79\left(1 \mathrm{H}, \mathrm{m}, \mathrm{H}-9^{\prime} \mathrm{a}\right), 3.37\left(1 \mathrm{H}, \mathrm{m}, \mathrm{H}-9^{\prime} \mathrm{b}\right)\right]$, and four methoxyls [ $\delta_{\mathrm{H}} 3.89(6 \mathrm{H}, \mathrm{s}), 3.85(3 \mathrm{H}$, s), $3.84(3 \mathrm{H}, \mathrm{s})]$. The ${ }^{13} \mathrm{C}-\mathrm{NMR}$ spectrum displayed 28 carbon signals, including a chelated phenolic ketone carbon, eighteen olefinic carbons, three methines, two methylenes, and four methoxyls (Table 1). The above-NMR of $\mathbf{2}$ resembled those of $\mathbf{1}$, except for the absence of a methylene, and the present of a $1^{\prime \prime}, 3^{\prime \prime}, 4^{\prime \prime}$-trisubstitution phenyl ring and a methine at $\left(\delta_{C} 74.5\right)$. The signal at $\delta_{C} 74.5$ was assigned to $\mathrm{C}-8^{\prime}$ indicated the $1^{\prime \prime}, 3^{\prime \prime}, 4^{\prime \prime}$-trisubstitution phenyl ring substituted there, which was supported by the HMBC correlations between $\mathrm{H}-8^{\prime}$ and C-2 ${ }^{\prime \prime} / \mathrm{C}-6^{\prime \prime}$. Furthermore, the HMBC correlations between $\mathrm{H}-7^{\prime}$ and $\mathrm{C}-4^{\prime}$ confirmed the $\mathrm{C}-4^{\prime}-\mathrm{O}-\mathrm{C}-7^{\prime}$ bond existence, and correlations between methoxy $\left(\delta_{\mathrm{H}} 3.84\right)$ and $\mathrm{C}-3^{\prime \prime}$, led to the methoxy substitution position at C-3" (Figure 4). Thus, the planar structure of 2 was determined, as shown in Figure 4.

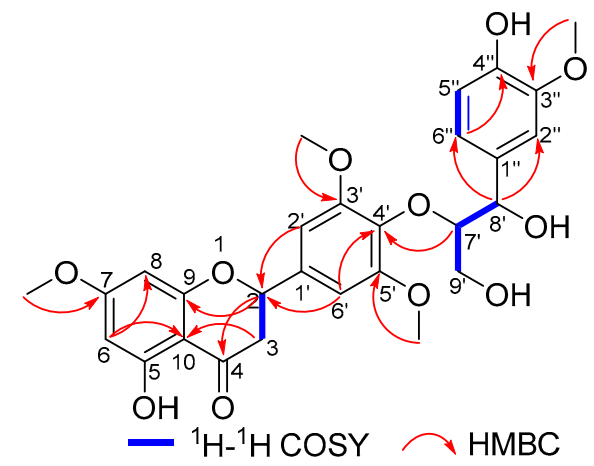

Figure 4. ${ }^{1} \mathrm{H}-{ }^{1} \mathrm{H}$ COSY and key HMBC correlations of 2.

Generally, adjacent protons of the erythro type have been reported to have smaller coupling constants $(2.8-5.6 \mathrm{~Hz})$ than those of the threo type $(6.0-8.6 \mathrm{~Hz})$ in different $d$-solvents [21-23]. Likewise, compound 2 was identified as a threo-configuration due to the $6.7 \mathrm{~Hz}$ coupling constants between $\mathrm{H}-\mathrm{7}^{\prime}$ and $\mathrm{H}-8^{\prime}$ in $\mathrm{CD}_{3} \mathrm{OD}$. Furthermore, the agreement of the ECD spectrum of $\mathbf{2}$ with those of $\mathbf{1}$ allowed the absolute configuration of $\mathbf{2}$ to be determined as $2 S$ (Figure 3).

The pharmacological study of flavonoids and their derivatives showed that they possess cytotoxic activity [24]. Thus, the flavonoid compounds (1-8) were tested for their cytotoxic activity against three human cancer cells MCF-7, HepG2, and A-549 using MTT assay. Compounds 1 and 2 exhibited a moderate cytotoxic activity against HepG2 cell lines with $\mathrm{IC}_{50}$ values of 49.8 and $53.6 \mu \mathrm{M}$, respectively (Table 2).

Table 2. Cytotoxicity of compounds $\mathbf{1 - 8}\left(\mathrm{IC}_{50}, \mu \mathrm{M}\right)$.

\begin{tabular}{cccc}
\hline Compound & MCF-7 & A-549 & HepG2 \\
\hline $\mathbf{1}$ & $>100$ & $>100$ & 49.8 \\
$\mathbf{2}$ & $>100$ & $>100$ & 53.6 \\
$\mathbf{3}$ & $>100$ & $>100$ & $>100$ \\
$\mathbf{4}$ & $>100$ & $>100$ & $>100$ \\
$\mathbf{5}$ & $>100$ & $>100$ & $>100$ \\
$\mathbf{6}$ & $>100$ & $>100$ & 89.6 \\
$\mathbf{7}$ & $>100$ & $>100$ & $>100$ \\
$\mathbf{8}$ & $>100$ & $>100$ & $>100$ \\
cisplatin & 19.8 & 15.3 & 17.6 \\
\hline
\end{tabular}




\section{Materials and Methods}

\subsection{General Experimental Procedures}

Optical rotation was carried out using a Jasco P-1020 digital polarimeter (JASCO, Tokyo, Japan). UV spectra were obtained on a Jasco V-550 UV/VIS spectrometer (JASCO, Tokyo, Japan), and IR spectra on a Jasco FT/IR-480 plus infrared spectrometer (JASCO, Tokyo, Japan) with KBr discs. HR-ESI-MS data were detected on an Agilent 6210 ESI/TOF mass spectrometer (Agilent, Palo Alto, CA, USA). NMR spectra were recorded on Bruker AV-500 spectrometer (Bruker, Karlsruhe, Germany). Column chromatography (CC) was performed on silica gel (80 100 and 200 300 mesh; Qingdao Marine Chemical Inc., Qingdao, China), ODS (YMC, Kyoto, Japan) and Sephadex LH-20 (Pharmacia Biotech AB). Preparative HPLC was carried out on an Agilent 1260 system (G1311 pump and G1315D photodiode array detector) with a $C_{18}$ reversed-phase column $(20 \times 250 \mathrm{~mm}, 5 \mu \mathrm{m}$, Shiseido Fine Chemicals Ltd., Osaka, Japan).

\subsection{Plant Material}

The areca nuts were collected in Sanya, Hainan province, P. R. China, in October 2014, and identified by Professor Guang-Xiong Zhou (College of Pharmacy, Jinan University). A voucher specimen (No. CP2014101403) was deposited at the herbarium of the College of Pharmacy, Jinan University, Guangzhou, P. R. China.

\subsection{Extraction and Isolation}

The air-dried and powdered areca nuts $(30.0 \mathrm{~kg})$ were extracted at room temperature with $95 \%$ EtOH to afford a residue $(1.1 \mathrm{~kg})$, which was then suspended in $\mathrm{H}_{2} \mathrm{O}$ and treated with $0.5 \%$ hydrochloric acid to adjust the $\mathrm{pH}$ to 2 to 3 . After extraction with $\mathrm{CHCl}_{3}$, the $\mathrm{CHCl}_{3}$ extract $(60.0 \mathrm{~g})$ was subjected to silica gel column chromatography and eluted with $\mathrm{CHCl}_{3}-\mathrm{CH}_{3} \mathrm{OH}(100: 0 \rightarrow 0: 100)$ to afford 8 fractions (Fr. A-H). Fr. D (2.8 g) was chromatographed on Sephadex LH-20 $\left(\mathrm{CHCl}_{3}-\mathrm{CH}_{3} \mathrm{OH}, 1: 1\right)$ and HPLC $\left(\mathrm{CH}_{3} \mathrm{OH}-\mathrm{H}_{2} \mathrm{O}, 35: 65\right)$ to afford 1 (7.2 mg, $\left.t_{\mathrm{R}} 14.3 \mathrm{~min}\right), 2\left(6.8 \mathrm{mg}, t_{\mathrm{R}} 28.7 \mathrm{~min}\right), 3\left(10.4 \mathrm{mg}, t_{\mathrm{R}} 37.6 \mathrm{~min}\right)$. Fr. E (5.9 g) was separated by Sephadex LH-20 $\left(\mathrm{CHCl}_{3}-\mathrm{CH}_{3} \mathrm{OH}, 1: 1\right)$ and further $\mathrm{HPLC}\left(\mathrm{CH}_{3} \mathrm{OH}-\mathrm{H}_{2} \mathrm{O}\right.$, 50:50) to afford $9\left(35.8 \mathrm{mg}, t_{\mathrm{R}} 17.8 \mathrm{~min}\right)$ and $11\left(26.3 \mathrm{mg}, t_{\mathrm{R}} 29.8 \mathrm{~min}\right)$. Fr. F (2.3 g) was subjected to ODS CC $\left(\mathrm{CH}_{3} \mathrm{OH}-\mathrm{H}_{2} \mathrm{O}, 1: 9 \rightarrow 7: 3\right)$ and $\mathrm{HPLC}\left(\mathrm{CH}_{3} \mathrm{OH}-\mathrm{H}_{2} \mathrm{O}, 40: 60\right)$ to yield $4\left(9.2 \mathrm{mg}, t_{\mathrm{R}} 40.4 \mathrm{~min}\right)$, $7\left(6.7 \mathrm{mg}, t_{\mathrm{R}} 25.8 \mathrm{~min}\right), 8\left(8.3 \mathrm{~g}, t_{\mathrm{R}} 33.8 \mathrm{~min}\right), \mathbf{1 0}\left(12.3 \mathrm{~g}, t_{\mathrm{R}} 19.6 \mathrm{~min}\right)$. Fr. G (1.9 g) was separated by Sephadex LH-20 $\left(\mathrm{CHCl}_{3}-\mathrm{CH}_{3} \mathrm{OH}, 1: 1\right)$ and further $\mathrm{HPLC}\left(\mathrm{CH}_{3} \mathrm{OH}-\mathrm{H}_{2} \mathrm{O}, 40: 60\right)$ to afford $5\left(12.2 \mathrm{mg}, t_{\mathrm{R}}\right.$ $24.1 \mathrm{~min})$ and 6 (10.5 $\left.\mathrm{mg}, t_{\mathrm{R}} 35.8 \mathrm{~min}\right)$.

Calquiquelignan $\mathrm{M}(\mathbf{1})$ : yellow powder; $[\alpha]_{\mathrm{D}}^{25}-8.9\left(c 0.36, \mathrm{CH}_{3} \mathrm{OH}\right) ; \mathrm{UV}\left(\mathrm{CH}_{3} \mathrm{OH}\right) \lambda_{\max }(\log \varepsilon)$ : 208 (4.14), 287 (3.88) nm; CD ( $\left.\mathrm{CH}_{3} \mathrm{OH}, \Delta \varepsilon\right) \lambda_{\max }$ : 342 (+6.6), 299 (-7.0), 260 (+29.3), 216 (-18.2) nm; IR $(\mathrm{KBr}) v_{\max } 3477,1660,1621,1535,1450,1304,1158,1114 \mathrm{~cm}^{-1} ;{ }^{1} \mathrm{H}$ - and ${ }^{13} \mathrm{C}-\mathrm{NMR}$ spectral data, see Table 1; HR-ESI-MS: $m / z$ [M + Na $]^{+}$, calcd for $\mathrm{C}_{21} \mathrm{H}_{24} \mathrm{O}_{9} \mathrm{Na}: 443.1313$, found: 443.1310 .

Calquiquelignan $\mathrm{N}(2)$ : yellow powder; $[\alpha]_{\mathrm{D}}^{25}-13.5\left(c 0.47, \mathrm{CH}_{3} \mathrm{OH}\right) ; \mathrm{UV}\left(\mathrm{CH}_{3} \mathrm{OH}\right) \lambda_{\max }(\log \varepsilon)$ : 208 (4.45), 230 (4.02), 287 (4.05) nm; CD ( $\left.\mathrm{CH}_{3} \mathrm{OH}, \Delta \varepsilon\right) \lambda_{\max }: 324$ (+2.5), 299 (-7.9), 250 (+3.4), 211 (-11.3) $\mathrm{nm}$; IR (KBr) $v_{\max } 3443,1651,1511,1429,1362,1032,826 \mathrm{~cm}^{-1} ;{ }^{1} \mathrm{H}$ - and ${ }^{13} \mathrm{C}-\mathrm{NMR}$ spectral data, see Table 1; HR-ESI-MS: $m / z$ [M + Na] ${ }^{+}$calcd for $\mathrm{C}_{28} \mathrm{H}_{30} \mathrm{O}_{11} \mathrm{Na}$ : 565.1680, found: 565.1685 .

${ }^{1} \mathrm{H}$ - and ${ }^{13} \mathrm{C}-\mathrm{NMR}$ spectra of these compounds are available in the Supplementary Materials.

\subsection{Computational Calculation}

Conformational searches were performed in the Sybyl 8.1 software by using the MMFF94S molecular force field, which afforded 12 conformers for 1 , with an energy cutoff of $10 \mathrm{kcal} / \mathrm{mol}$. The ECD calculation for the optimized conformers was carried out using time-dependent DFT (TDDFT) methods at the B3LYP/6-31+G(d) level in the gas phase by using Gaussian 09 software. The overall ECD curves of 1 were weighted by Boltzmann distribution of each conformer (with a half-bandwidth 
of $0.3 \mathrm{eV})$. The calculated ECD spectra of $\mathbf{1}$ were subsequently compared with the experimental ones. The ECD curves were produced by SpecDis 1.6 software (University of Wuerzburg, Bavaria, Germany).

\subsection{Cytotoxicity Assay}

The MTT assay for the determination of the cytotoxicity was performed as described previously [25]. Briefly, cancer cells were plated into 96-well plates. After $48 \mathrm{~h}$ of preculture, the cells were treated with compounds at various concentrations for $72 \mathrm{~h}$ and then stained with MTT. Absorbance at $570 \mathrm{~nm}$ was measured on a microplate reader.

\section{Conclusions}

In summary, we isolated two new flavonoids, calquiquelignan $\mathrm{M}$ and $\mathrm{N}(\mathbf{1}-\mathbf{2})$ and nine known compounds naringenin (3), dihydrotricin (4), sinesetin (5), nobiletin (6), 8-demethyleucalyptin (7), eucalyptin (8), (+)-isolariciresinol (9), rhapontigenin (10), glyceryl-2-vanillic acid methyl ester (11) from the nuts of $A$. catechu. The new compounds were elucidated by spectroscopic analyses, and computational calculation, and the known ones were identified by comparing their spectroscopic data with reported in the literature. Moreover, all of the flavonoids (1-8) were evaluated for their cytotoxicity activities against three human cancer cell lines. Compounds $\mathbf{1}$ and $\mathbf{2}$ showed moderate cytotoxicity against HepG2 cell lines with $\mathrm{IC}_{50}$ values of 49.8 and $53.6 \mu \mathrm{M}$, respectively.

Supplementary Materials: The following are available online, Computational data of $\mathbf{1}$. Cytotoxicity assay. Figures S1-S9: HRESIMS, UV, IR, 1D, and 2D-NMR spectra of compound 1. Figures S10-S17: HRESIMS, UV, IR, 1D, and 2D-NMR spectra of compound 2.

Author Contributions: M.Y., Y.A., and J.X. isolated and identified the structure of the compounds. N.Y. and D.Z carried out the cytotoxicity assay. J.Z. and X.Z. designed and supervised the study, and wrote and revised the manuscript. W.Y. revised the manuscript.

Funding: This research was funded by the National Key R\&D Program of China (No. 2017YFC1703802), the National Natural Science Foundation of China (Nos. U1801287, 81630095, and 81803377), the Science and Technology Planning Project of Guangdong Province (No. 2016B030301004 and 2018B020207008), the Guangdong Medical Products Administration (No. 2018TDZ21), the Natural Science Foundation of Guangdong Province (NO. 2018A030310640).

Conflicts of Interest: The authors declare no conflict of interest.

\section{References}

1. Srimany, A.; George, C.; Naik, H.R.; Pinto, D.G.; Chandrakumar, N.; Pradeep, T. Development patterning and segregation of alkaloids in arece nut (seed of Areca catechu) revealed by magnetic resonance and mass spectrometry imaging. Phytochemistry 2016, 125, 35-42. [CrossRef] [PubMed]

2. Tsai, C.C.; Kao, C.T.; Hsu, C.T.; Lin, C.C.; Lin, J.G. Evaluation of four prescriptions of traditional Chinese medicine: Syh-mo-yiin, guizhi-fuling-wan, shieh-qing-wan and syh-nih-sann on experimental acute liver damage in rats. J. Ethnopharmacol. 1997, 55, 213-222. [CrossRef]

3. Lin, Q.H.; Jia, Z.; Xu, X.F.; Xu, S.Y.; Han, T.; Gao, Y.; Zhang, Y.; Zhang, H.; Liu, H.; Li, J.; et al. Sub-chronic toxicity study of areca semen aqueous extract in Wistar rats. J. Ethnopharmacol. 2018, 215, 176-183. [CrossRef] [PubMed]

4. Pithayanukul, P.; Nithitanakool, S.; Bavovada, R. Hepatoprotective potential of extracts from seeds of Areca catechu and nutgalls of Quercus infectoria. Molecules 2009, 14, 4987-5000. [CrossRef] [PubMed]

5. Anjali, S.; Rao, A.R. Modulatory influence of arecanut on antioxidant 2(3)-tert-butyl-4-hydroxy anisole-induced hepatic detoxification system and antioxidant defense mechanism in mice. Cancer Lett. 1995, 91, 107-114.

6. Shao, M.; Wang, Y.; Jian, Y.Q.; Huang, X.J.; Zhang, D.M.; Tang, Q.F.; Jiang, R.W.; Sun, X.G.; Lv, Z.P.; Zhang, X.Q.; et al. Guadial A and psiguadials C and D, three unusual meroterpenoids from Psidium guajava. Org. Lett. 2012, 14, 5262-5265. [CrossRef] [PubMed]

7. Tang, B.Q.; Wang, W.J.; Huang, X.J.; Li, G.Q.; Wang, L.; Jiang, R.W.; Yang, T.T.; Shi, L.; Zhang, X.Q.; Ye, W.C. Iboga-type Alkaloids from Ervatamia hainanensis. J. Nat. Prod. 2014, 77, 1839-1846. [CrossRef] [PubMed] 
8. Zhang, J.; Ding, Y.; Huang, X.J.; Jiang, R.W.; Wang, Y.; Sun, P.H.; Fan, R.Z.; Zhang, X.Q.; Ye, W.C. Melohemsines A-I, melodius-type alkaloids from Melodinus hemsleyanus. RSC Adv. 2016, 6, 92218-92224. [CrossRef]

9. Liu, Z.W.; Zhang, J.; Li, S.T.; Liu, M.Q.; Huang, X.J.; Ao, Y.L.; Fan, C.L.; Zhang, D.M.; Zhang, Q.W.; Ye, W.C.; et al. Ervadivamines A and B, two unusual trimeric monoterpenoid indole alkaloids from Ervatamia divaricate. J. Org. Chem. 2018, 83, 10613-10618. [CrossRef]

10. Kuok, C.F.; Zhang, J.; Fan, C.L.; Zhang, Q.W.; Fan, R.Z.; Zhang, D.M.; Zhang, X.Q.; Ye, W.C. Meloslines A and B, two novel indole alkaloids from Alstonia scholaris. Tetrahedron Lett. 2017, 58, 2740-2742. [CrossRef]

11. Tang, S.N.; Zhang, J.; Liu, D.; Liu, Z.W.; Zhang, X.Q.; Ye, W.C. Three new areca alkaloids from the nuts of Areca catechu. J. Asian Nat. Prod. Res. 2017, 19, 1155-1159. [CrossRef] [PubMed]

12. Smejkal, K.; Grycova, L.; Marek, R.; Lemiere, F.; Jankovska, D.; Forejtnikova, H.; Vanco, J.; Suchy, V. C-Geranyl compounds from Paulownia tomentosa fruits. J. Nat. Prod. 2007, 70, 1244-1248. [CrossRef] [PubMed]

13. Jeon, S.H.; Chun, W.; Choi, Y.J.; Kwon, Y.S. Cytotoxic constituents from the bark of Salix hulteni. Arch. Pharm. Res. 2008, 31, 978-982. [CrossRef] [PubMed]

14. Okuno, Y.; Miyazawa, M. Microbial O-demethylation of sinesetin and antimutagenic activity of the metabolite. J. Chem. Technol. Biot. 2006, 81, 29-33. [CrossRef]

15. Han, S.; Kim, H.M.; Lee, J.M.; Mok, S.Y.; Lee, S. Isolation and identification of polymethoxyflavones from the Hybrid citrus Hallabong. J. Agric. Food Chem. 2010, 58, 9488-9491. [CrossRef] [PubMed]

16. Park, S.Y.; Lim, J.Y.; Jeong, W.; Hong, S.S.; Yang, T.T.; Hwang, B.Y.; Lee, D. C-methylflavonoids isolated from Callistemon lanceolatus protect PC12 cells against A $\beta$-induced toxicity. Planta Med. 2010, 76, 863-868. [CrossRef] [PubMed]

17. Ruan, J.Y.; Li, Z.; Yan, J.Q.; Huang, P.J.; Yu, H.Y.; Han, L.F.; Zhang, Y.; Wang, T. Bioactive constituents from the aerial parts of Pluchea indica less. Molecules 2018, 23, 2104. [CrossRef] [PubMed]

18. Lee, D.; Park, S.; Choi, S.; Kim, S.H.; Kang, K.S. In vitro estrogenic and breast cancer inhibitory activities of chemical constituents isolated from Rheum undulatum L. Molecules 2018, 23, 1215. [CrossRef] [PubMed]

19. Katayama, T.; Nakatsubo, F.; Higuchi, T. Degradation of arylglycerol-b-aryl ethers, lignin substructure models, by Fusarium solani. Arch. Microbiol. 1981, 130, 198-203. [CrossRef]

20. Li, X.C.; Ferreira, D.; Ding, Y.Q. Determination of absolute configuration of natural products: Theoretical calculation of electronic circular dichroism as a tool. Curr. Org. Chem. 2010, 14, 1678-1697. [CrossRef]

21. Bouaziz, M.; Veitch, N.C.; Grayer, R.J.; Simmonds, M.S.J.; Damak, M. Flavonolignans from Hyparrhenia hirta. Phytochemistry 2002, 60, 515-520. [CrossRef]

22. Nakajima, Y.; Yun, Y.S.; Kunugi, A. Six new flavonolignans from Sasa veitchii, (Carr.) Rehder. Tetrahedron 2003, 59, 8011-8015. [CrossRef]

23. Gan, M.L.; Zhang, Y.L.; Lin, S.; Liu, M.Y.; Song, W.X.; Zi, J.C.; Yang, Y.C.; Fan, X.N.; Shi, J.G.; Hu, J.F.; et al. Glycosides from the root of Iodes cirrhosa. J. Nat. Prod. 2008, 71, 647-654. [CrossRef] [PubMed]

24. Taleghani, A.; Tayarani-Najaran, Z. Potent cytotoxic natural flavonoids: The limits of perspective. Curr. Pharm. Des. 2018, 24, 5555-5579. [CrossRef] [PubMed]

25. Suzuki, K.; Kuwahara, A.; Yoshida, H.; Fujita, S.; Nishikiori, T.; Nakagawa, T. NF00659A1, A2, A3, B1 and B2, novel antitumor antibiotics produced by Aspergillus sp. NF 00659. I. Taxonomy, fermentation, isolation and biological activities. J. Antibiot. 1997, 50, 314-317. [CrossRef] [PubMed]

Sample Availability: Samples of the compounds 1-11 are available from the authors.

(C) 2019 by the authors. Licensee MDPI, Basel, Switzerland. This article is an open access article distributed under the terms and conditions of the Creative Commons Attribution (CC BY) license (http://creativecommons.org/licenses/by/4.0/). 